\title{
EFFECT OF CHEESE WHEY AND POLY-ETHYLENE GLYCOL ON PERFORMANCE OF GROWING LAMBS FED PEANUT HULLS ENSILED WITH LIME AND UREA
}

\author{
Y.I. EL-Talty ${ }^{1}$, M.S. Farghaly ${ }^{1}$ and R.S. Mikail ${ }^{2}$
}

1- Animal Production Department, Faculty of Agriculture, Cairo University, Giza, Egypt, 2-Animal Production Research Institute, Agriculture Research Center, Ministry of Agriculture, , Giza, Egypt

\section{SUMMARY}

This study included two experiments, the first was carried out to study the effect of treating peanut hulls chemically by ensiling with 5\% lime $+5 \%$ urea on its chemical composition and nutritive value by using adult crossbred (Romanov $x$ Rahmani) rams. The second was carried out to study the effect of adding fresh sweet liquid cheese whey (FSLCW) or/and Poly-Ethylene Glycol (PEG) on the performance and feed efficiency of crossbred (Romanov $\times$ Rahmani) growing lambs fed total mixed rations (TMR) consisting of $40 \%$ roughag and $60 \%$ concentrate mixture for 70 days. Twenty male lambs with an average body weight $28.85 \mathrm{~kg}$ and 6 months old were divided into four equal groups and randomly assigned to fed one of the following experimental rations :

$\left(T_{1}\right)$ control ration: contains wheat bran $15 \%$, barely $29 \%$, soya-bean meal $8.5 \%$, clover hay (Trifolium alexandrinum) 40\%, sugar cane-molasses 4\%, lime stone $2 \%$,common salt $1 \%$ and vits. \& mins. mixture $0.5 \%$.

$\left(T_{2}\right): T_{1}$ with replacing all of the clover hay by treated peanut hulls .

$\left(T_{3}\right): T_{2}$ plus FSLCW( free choice) .

(T $\left.T_{4}\right): T_{2}$ plus FSLCW( free choice) plus $3 \mathrm{~g} P E G$ / head / day.

The ingested daily of the cheese whey expressed as TDN was replaced with a part of $T_{2}$ having the same value of TDN. The experimental animals were given their requirements of energy and protein to cover their average daily gain (NRC,1985). At the end of feeding trial four digestion, trials were conducted. Some rumen liquor and some blood parameters were also studded.

The results of the first experiment showed that total phenols and total tannins nearly disappeared in treated peanut hulls. In addition. digestibilities of $C P, C F$, NFE and nutritive values as TDN and DCP decreased from $36.9 \%, 18.55 \%, 70.36$ $\%, 31.47 \%$ and $2.51 \%$ to $6.31 \%, 10.17 \%, 44.04 \%, 16.86 \%$ and $0.63 \%$, respectively. In the second experiment, there were:

1) Significant increase in digestibilities of CP from $60.53 \%$ to $75.03 \%$ vs.

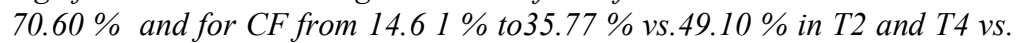
T1 respectively.

2) Significant increase in the feeding values in terms of TDN and DCP from $52.19 \%$ to $63.29 \%$ vs. $61.18 \%$ and from $10.07 \%$ to $12.32 \%$ vs. 11.93 $\%$ in $T 2$ and $T 4$ vs. $T 1$, respectively.

3) Significant increase in the average daily weight gain from97 to $197 \mathrm{vs.} 151 \mathrm{~g}$ I day in T2 and T4 vs. T1, respectively.

4) Improving in feed conversion of DM and TDN from 12.01 to 7.77 and from 6.27 to 4.91, g feed / g gain, respectively.

Issued by The Egyptian Society of Animal Production 
5) Due to the decrease in feeding costs and increase in the average daily weight gain, relative profit expressed as net profit / feeding cost increased to $151.52 \%$ and $190.6 \%$ in $T_{3}$ containing FSLCW (free choice) and $T_{4}$ containing FSLCW (free choice) plus $3 \mathrm{~g} P E G$ / head / day vs. $T_{1}(59.62 \%)$ containing $40 \%$ clover hay, respectively.

Generally, it could be concluded that, in complete ration containing $40 \%$ clover hay, it is possible to replace the hay by peanut hulls ensiled with $5 \%$ lime $+5 \%$ urea with adding fresh sweet liquid cheese whey (free choice) and $3 g$ PEG / head /day in growing lambs rations to improve their performance and economic efficiency.

Keywords: Peanut hulls, lime, urea, cheese whey, Poly-Ethylene Glycol, sheep

\section{INTRODUCTION}

A wide variety of agricultural residues and by-products showed varying degrees of success when fed to ruminants. These feeds are imbalance in nutrients content and most of them are deficient in protein content. In addition, the abundant energy stored in the cellulose and hemi-cellulose content of the cell walls is not readily available for digestion by rumen micro-organisms. Digestion of highly fibrous materials in ruminants is severely limited by the presence of lignin (El-Talty, 1970 and 1973; Theander and Aman, 1984 and Aguilera, 1987). Moreover, the digestibility and intake of these residues tended to be lower with the higher lignifications levels. Many of tanniniferous feeds as peanut hulls could be useful as livestock fodders. But, various secondary compounds in these fodders may be toxic to animals or cause a reduction in their productivity (Barry and Blaney, 1987). Gow-Chin Yen and Pin-Der Duh (1995) reported that peanut hulls contains total phenolic compounds reaches to $10.2 \mathrm{mg} / \mathrm{g}$. The occurrence of tannins or phenolic substances in feeds may inhibit rumen cellulolytic activity (Theriez and Boule,1970). Cheese whey which is an environmental pollutant by-product was found to have a good nutritional value in animals feeding. This by-product represents about $85-95 \%$ of the milk volume and retains $55 \%$ of whey nutrients . These nutrients are lactose $(4.5-5 \% \mathrm{w} / \mathrm{v})$, soluble proteins $(0.6-0.8 \% \mathrm{w} / \mathrm{v})$, lipids $(0.4-0.5 \% \mathrm{w} / \mathrm{v})$ and mineral salts $(8-10 \%$ of dried extract) (Gonzalez,1996). Therefore, many studies were carried out to maximize the utilization of certain by-products as peanut hulls and cheese whey in animal feeding. Franklin et al.,1974 treated peanut hulls chemically and found wide variations in IVDMD (from 11.8\% to 40\%). Kaneko et al., 1989 and Silanikove et al., 2001 found that cheese whey and Polyethylene glycol have positive effects on the rumen microflora of animals fed on tanniniferous by-products .

Therefore, this study was designed to evaluate the ensiled peanut hulls with 5\% lime plus $5 \%$ urea as well as to investigate the effect of its incorporating in the rations with fresh sweet liquid cheese whey (FSLCW) and polyethylene glycol (PEG) as feed additive on the performance and economic efficiency of growing lambs.

\section{MATERIALS AND METHODS}

The present study was conducted at Mahlet-Mousa, Station, Kafr El-Sheikh Governorate. 
Bulk of ground peanut hulls ( 3 - $5 \mathrm{~mm}$ screen) was treated chemically by ensiling in anaerobic condition with a mixture of 5\% lime plus 5\% urea (on DM basis) for 28 days. The moisture content was adjusted to be $45 \%$. The treated materials were ensiled in ground silos $(2 \times 2 \times 1 \mathrm{~m})$. After 28 days, the ensiled materials laid out in a sunny place to lose the excess of ammonia and moisture.

The first experiment was designed to evaluate the ensiled peanut hulls. Eighteen crossbred ( Romanov x Rahmani) rams weighing $55 \mathrm{~kg}$ in average were used to evaluate the effect of ensiling peanut hulls on its chemical composition and digestibility coefficients, through six metabolism trails. Animals were divided into six groups. Each group was allowed randomly to fed on one of the following rations:

$\mathrm{R}_{1}:(200 \mathrm{gm}$ starch $+15 \mathrm{~g}$ urea) $/$ head /day + untreated peanut hulls (was offered ad. lib.).

$\mathrm{R}_{2}$ : Clover hay+ untreated peanut hulls (1:1 air dry basis) (was offered ad. lib.).

$\mathrm{R}_{3} \quad$ : Barley + untreated peanut hulls (1:1 air dry basis) (was offered $a d$. lib.).

$\mathrm{R}_{4} \quad$ : (200 gm starch $+15 \mathrm{~g}$ urea $) /$ head /day + treated peanut hulls (was offered ad. lib.).

$\mathrm{R}_{5} \quad$ : Clover hay + treated peanut hulls (1:1 air dry basis) (was offered $\left.a d . l i b.\right)$.

$\mathrm{R}_{6} \quad$ : Barley + treated peanut hulls (1:1 air dry basis) (was offered $a d$. lib.).

Mixture of vitamins and minerals was added to cover the requirements according to NRC, 1985 for sheep.

The second experiment was designed to investigate the effect of adding FSLCW as a sole liquid with or without PEG to ensiled peanut hulls in lambs rations on animals performance. Four total mixed rations (TMR) were formulated to contain concentrate and roughage ratio at 60:40 as the following table:.

Composition of the experimental rations

\begin{tabular}{|c|c|c|c|c|}
\hline \multirow[t]{2}{*}{ Feed ingredients } & \multicolumn{3}{|c|}{ Experimental rations } & \multirow[b]{2}{*}{$\mathbf{T}_{4}$} \\
\hline & $T_{1}$ & $\mathbf{T}_{2}$ & $\mathbf{T}_{3}$ & \\
\hline Wheat bran & 15.0 & 15.0 & 15.0 & 15.0 \\
\hline Barely & 29.0 & 29.0 & 29.0 & 29.0 \\
\hline Soya-bean meal & 8.5 & 8.5 & 8.5 & 8.5 \\
\hline Clover hay & 40.0 & - & - & - \\
\hline Treated peanut hulls & - & 40.0 & 40.0 & 40.0 \\
\hline Sugar cane-Molasses & 4.0 & 5.0 & 5.0 & 5.0 \\
\hline Lime stone & 2.0 & - & - & - \\
\hline Common salt & 1.0 & 1.0 & 1.0 & 1.0 \\
\hline Vits. \& mins. mix. & 0.5 & 0.5 & 0.5 & 0.5 \\
\hline Urea & - & 1.0 & 1.0 & 1.0 \\
\hline TDN(calculated) & 58.6 & 50.6 & 50.6 & 50.6 \\
\hline Poly Ethylene Glycol (PEG) & - & - & - & + \\
\hline $\begin{array}{l}\text { Fresh sweet liquid cheese } \\
\text { whey }\end{array}$ & - & - & $a d-l i b$ & $a d-l i b$ \\
\hline
\end{tabular}


$+: 3 \mathrm{~g} \mathrm{PEG} / \mathrm{head} /$ day.

The control ration $\left(\mathrm{T}_{1}\right)$ was formulated to contain $15 \%$ wheat bran, $29 \%$ barley, $8.5 \%$ soybean meal, $4 \%$ molasses, $2 \%$ limestone, $1 \%$ common salt, $0.5 \%$ vits.\& mins. mixture and $40 \%$ clover hay. Treatments $\mathrm{T}_{2}, \mathrm{~T}_{3}$ and $\mathrm{T}_{4}$ were formulated to replace all of clover hay by treated peanut hulls. Fresh sweet liquid cheese whey was offered in $T_{3}$ and $T_{4}$ free choice. Polyethylene glycol was given to the lambs in $\mathrm{T}_{4}$ at $3 \mathrm{~g} / \mathrm{head} /$ day with the drinking water. Twenty males of growing crossbred ( Romanov x Rahmani) lambs were about 6 months old and weighing $28.85 \pm 1.39 \mathrm{~kg}$ in average. Animals were allocated equally to four groups using a complete randomized design and housed in separate pens for 70 days. The daily requirements of the experimental rations (DM basis) were calculated according to (NRC, 1985). The air dried whey has TDN $78 \%$ and DM 94\% (CLFF, 2001) :

$$
\begin{aligned}
& \text { Averagedaily DM }(\mathrm{Kg})=\frac{0.03 \mathrm{~W}^{0.75}(1+5.5 \mathrm{~A})-\mathrm{Vx} \text { liquid whey TDN } \%}{\text { Ration TDN\% }} \\
& \mathrm{W}=\text { Empty body weight } \\
& \mathrm{A}=\text { Average daily gain } \\
& \mathrm{V}=\text { Volume of liquid whey in liter }
\end{aligned}
$$

Drinking water or FSLCW was available freely for animals all the time after feeding. At the end of feeding trials, three animals from each group were randomly chosen for a digestion trial in which the FSLCW was offered daily as the recorded average during the whole feeding period $\left(\mathrm{T}_{3}\right.$ and $\left.\mathrm{T}_{4}\right)$. At the end of digestion trials, samples of rumen liquor were taken from the same animals just before morning feeding and then at two and four hours after feeding. Rumen samples were taken through stomach tube then filtered through two layers mesh cloth. Collected samples of rumen liquor were immediately determined for $\mathrm{pH}$, then $\mathrm{NH} 3-\mathrm{N}$ concentration according to Conway (1962) and TVFA's concentration according to Warner (1964). Blood samples were taken at $24 \mathrm{hrs}$. post morning feeding from the jugular vein. Blood serum was obtained and tested for total protein (Henery,1964) and albumin (Doumas, 1971). Globulin was calculated by the difference between total protein and albumin. Blood levels of GOT and GPT transaminases were determined according to Reitman and Frankel (1957). Samples of feeds and feces were analyzed according to AOAC (1990), while total phenols and tannins of untreated and ensilage treated peanut hulls were determined according to Folin-Ciocalteu method (Slinkard and Singleton, 1977).

Data obtained in this study was statistically analyzed according to SAS (1990). Significant differences were tested among means according to Duncan's multiple range test (1955).

\section{RESULTS AND DISCUSSION}

\section{First experiment:}

Effect of ensiling peanut hulls with $5 \%$ lime $+5 \%$ urea on chemical composition is presented in Tables (1) and (2). Results indicated that the content of total phenols and tannins decreased from $1.61 \%$ to $1.47 \%$ and from $1.33 \%$ to $1.11 \%$ by storing while, they nearly disappeared. In this connection, Russel and Lolley (1989) concluded that, tannin in high tannin milos could be deactivated rapidly and completely by reconstitution with aqueous urea. Price et al. (1979) and Reichert et al. 
(1980) reported similar results. On the other hand, it could be noticed that, ash and CP contents increased while CF decreased by ensiling with lime and urea being, $7.52,6.80$ and 64.08 vs. $12.47,9.93$ and $58.11 \%$, respectively. The increasing in ash and CP might be due to adding 5\% lime and 5\% urea (Sirohi and Rai, 1995 and Farghaly et al., 2003) while, the decrease in CF might due to the alkali treatments which reduces the strength of intermolecular hydrogen bonds (Granzin and Dryden, 2003).

Table 1. Total phenols and tannins of untreated and ensilage treated peanut hulls (DM basis)

\begin{tabular}{rccc}
\hline & \multicolumn{3}{c}{ Peanut hulls } \\
\cline { 2 - 4 } Items & $\mathrm{A}$ & $\mathrm{B}$ & $\mathrm{C}$ \\
\hline Total phenols \% & 1.61 & 1.47 & 0.15 \\
Total tannins \% & 1.33 & 1.11 & Nile \\
\hline
\end{tabular}

A. Untreated (after oil extraction directly).

B. Untreated (after storing for 3 months in a sunny place)

C. Ensiled with $5 \%$ lime $+5 \%$ urea.

Table 2. Chemical composition, digestion coefficients and nutritive value of peanut hulls

\begin{tabular}{|c|c|c|c|c|c|c|c|c|c|}
\hline \multirow{2}{*}{ Items } & \multirow{2}{*}{ DM } & \multicolumn{8}{|c|}{ (DM basis) } \\
\hline & & OM & $\mathbf{C P}$ & CF & $\mathbf{E E}$ & NFE & Ash & TDN & DCP \\
\hline \multicolumn{10}{|l|}{ Untreated: } \\
\hline Chemical Comp. & 92.05 & 92.48 & 6.80 & 64.08 & 1.89 & 19.71 & 7.52 & & \\
\hline \multicolumn{10}{|c|}{ Digestion coefficients and nutritive values: } \\
\hline By direct method & 29.60 & $31.93^{\mathrm{b}}$ & $36.90^{\mathrm{b}}$ & $18.55^{\mathrm{b}}$ & $82.34^{\mathrm{a}}$ & $70.36^{\mathrm{a}}$ & & 31.47 & 2.51 \\
\hline By difference (1) & 31.08 & $33.41^{\mathrm{b}}$ & $70.64^{\mathrm{a}}$ & $19.90^{\mathrm{b}}$ & $97.35^{\mathrm{a}}$ & $54.85^{\mathrm{b}}$ & & 33.20 & 4.80 \\
\hline By difference (2) & 40.00 & $43.09^{\mathrm{a}}$ & $64.19^{\mathrm{a}}$ & $28.85^{\mathrm{a}}$ & $87.18^{\mathrm{a}}$ & $71.95^{\mathrm{a}}$ & & 41.91 & 4.36 \\
\hline \multicolumn{10}{|l|}{ Treated } \\
\hline Chemical Comp. & 91.30 & 87.53 & 9.93 & 58.11 & 1.14 & 18.35 & 12.47 & & \\
\hline \multicolumn{10}{|c|}{ Digestion coefficients and nutritive values: } \\
\hline By direct method & 16.00 & $18.21^{\mathrm{d}}$ & $6.31^{\mathrm{c}}$ & $10.17^{\mathrm{c}}$ & $64.30^{\mathrm{b}}$ & $44.04^{\mathrm{bc}}$ & & 16.86 & 0.63 \\
\hline By difference $(1)$ & 21.47 & $24.39^{\mathrm{c}}$ & $11.98^{\mathrm{c}}$ & $23.02^{\mathrm{ab}}$ & $91.94^{\mathrm{a}}$ & $29.79^{\mathrm{cd}}$ & & 22.66 & 1.19 \\
\hline By difference (2) & 24.68 & $28.49^{\mathrm{bc}}$ & $28.60^{\mathrm{b}}$ & $30.52^{\mathrm{a}}$ & $65.25^{\mathrm{b}}$ & $23.46^{\mathrm{d}}$ & & 25.87 & 2.84 \\
\hline
\end{tabular}

a, b, c, d means in the same column with different superscripts differ at $(\mathrm{P}<0.05)$.

$\begin{array}{ll}\text { (1)With clover hay. } & \text { (2)With barley. }\end{array}$

Digestibility coefficients and nutritive value of peanut hulls were affected by ensiling treatment as shown in Table (2). Ensiling peanut hulls caused a significant decrease $(\mathrm{P}<0.05)$ in digestion coefficients of $\mathrm{DM}, \mathrm{OM}, \mathrm{CP}, \mathrm{CF}, \mathrm{EE}$, and NFE, being 16, 18.21, 6.31, 10.17, 64.3 and $44.04 \%$ vs. 29.6, 31.93, 36.9, 18.55, 82.34 and $70.36 \%$ for treated and untreated peanut hulls respectively .On the other hand TDN and DCP were decreased from 31.47 and 2.51 to 16.86 and 0.63 . The severe drop in $\mathrm{CP}, \mathrm{CF}$ and NFE digestibilities of peanut hulls due to the ensiling treatment may be explained by one or more reason. Strong alkali treatment (by ensiling peanut hulls with $5 \%$ lime $+5 \%$ urea) of the dietary protein may be depressed CP digestibility through formation of uncommon toxic amino acid which known as lysinoalanine (De Groot and Stump, 1969). Isomerization of the dietary protein (Provansal et al., 1975) and cross-linking within or between polypeptide chains (Aymard et al., 1979) may be another reason. Ammoniated of roughages may be produce sugar-ammonia compounds, which had toxic effects on animals (Nishie et al., 1969). Formation of 
these types of compounds during ensiling peanut hulls could be a reason for the noticeable severe drop in $\mathrm{CP}$ digestibility. The noticeable reduction in $\mathrm{CF}$ digestibility of peanut hulls $(10.17 \%)$ as affected by the ensiling treatment might be attributed to formation of potentially hazardous compounds which produce toxic effects especially on microflora in the rumen. Probably the most of these compounds resulted from the so-called nonenzymatic browning reaction (Maillard reaction) involving nitrogenous compounds (as urea, ammonia and dietary protein), carbohydrates (reducing sugars and water soluble carbohydrates), heat (as that produced during the ensiling which it was about $60^{\circ} \mathrm{C}$ ) and high $\mathrm{pH}$ values as adding lime and urea. In this connection Lee et al. (1975) found that the decrease in nutritional value by browning reaction was not only due to the degradation of amino acids, but also to the appearance of toxic materials. Moreover, Eskin et al. (1971) cited that high $\mathrm{pH}$ enhances nonenzymatic browning reactions (Maillard reaction) involving sugar by catalyzing their conversation to the highly reactive enediol form. Lignin that released by effect of ensiling peanut hulls with $5 \%$ lime $+5 \%$ urea is another compound ( phenolic compound) which might had hazard effects on the ruminal microflora (Hartley, 1981) and it might be associated with the other toxic compounds in reducing CF digestibility. The reduction in CF digestibility might also be explained by a decrease in ruminal cellulolytic activity as a result of alkali-ensiled peanut hulls with 5\% lime $+5 \%$ urea (Klopfenstein et al., 1979), or inhibition of microbial activity by phenolic acids which released by alkali. The reduction in CF digestibility also might be related to the rate of passage of digesta through the reticulo-rumen which decreased by ensiling peanut hulls with $5 \%$ lime $+5 \%$ urea (Ali et al., 1977). The observed severe reduction in NFE digestibility could be explained by forming undigested sugar-ammonia compounds ( Maillard reaction). These results confirmed with the findings by Nishie et al. (1969), Eskin et al. (1971) and Lee et al. (1975).

\section{Second experiment:}

Chemical composition of the experimental rations presented in Table (3) shows that the content of CP is nearly similar. Adding FSLCW in $T_{3}$ and $T_{4}$ caused a marked decrease in CF content by $21.8 \%$ and an increase in $\mathrm{EE}$ and ash contents by $142 \%$ and $24.8 \%$, respectively.

Data concerning digestibility and feeding value of the experimental rations presented in Table (4), indicates that digestibility coefficients of DM, OM,CP and CF of $\mathrm{T}_{4}$ were better $(\mathrm{P}<0.05)$ than those in $\mathrm{T}_{2}$ and $\mathrm{T}_{3}$. Using FSLCW in $\mathrm{T}_{3}$ improved $(\mathrm{P}<0.05)$ digestibility of $\mathrm{DM}$ and $\mathrm{CP}$ by $10.06 \%$ and $17.92 \%$ against unsupplemented ration $\left(\mathrm{T}_{2}\right)$ while the differences in digestibility of OM, EE and NFE were insignificant. Adding PEG in $\mathrm{T}_{4}$ improved $(\mathrm{P}<0.05)$ digestibility of $\mathrm{DM}, \mathrm{OM}$ and $\mathrm{CF}$ by $8.44 \%, 10 \%$ and $227.86 \%$ against unsupplemented ration $\left(\mathrm{T}_{3}\right)$ while the differences in digestibilities of CP, EE and NFE were insignificant . Comparing $\mathrm{T}_{4}$ whith $\mathrm{T}_{1}$, idicated that, the digestibilites of $\mathrm{DM}, \mathrm{OM}$ and EE were nearly similar being $63.10,65.76$ and 91.72 vs. $62.20,64.50$ and $89.33 \%$ respectively, while digestibilites of $\mathrm{CP}$ was higher $(\mathrm{P}<0.05)$ and of $\mathrm{CF}$ was lower $(\mathrm{P}<0.05)$ being 75.03 and 35.77 vs. 70.60 and $49.10 \%$ in $\mathrm{T}_{4}$ and $\mathrm{T}_{1}$ respectively. There was no significant difference between the experimental rations $T_{4}$ and $T_{1}$ in the nutritive values expressed as TDN (63.29 vs.61.18) and DCP (12.32 vs. 11.93). 
Table 3. Chemical analysis of the experimental rations (DM basis)

\begin{tabular}{lrrrc}
\hline Items & \multicolumn{5}{c}{ Experimental rations } \\
\cline { 2 - 5 } & T1 & T2 & T3 & T4 \\
\hline DM & 88.90 & 90.30 & 90.30 & 90.30 \\
OM & 91.50 & 92.23 & 90.30 & 90.30 \\
CP & 16.90 & 16.63 & 16.42 & 16.42 \\
CF & 18.10 & 28.78 & 22.50 & 22.50 \\
EE & 2.10 & 1.45 & 3.51 & 3.51 \\
NFE & 54.40 & 45.37 & 47.87 & 47.87 \\
Ash & 8.50 & 7.77 & 9.70 & 9.70 \\
\hline
\end{tabular}

Rations T3 and T4 contain $22 \%$ cheese whey (DM basis).T4 contain 3g PEG / head / day.

Table 4. Digestion coefficients and nutritive values of the experimental rations (DM basis)

\begin{tabular}{ccccc}
\hline Items & \multicolumn{4}{c}{ Experimental rations } \\
\cline { 2 - 5 } & $\mathrm{T} 1$ & $\mathrm{~T}_{2}$ & $\mathrm{~T}_{3}$ & $\mathrm{~T}_{4}$ \\
\hline Apparent digestibility: & & & & \\
DM & $62.20^{\mathrm{ab}}$ & $52.87^{\mathrm{d}}$ & $58.19^{\mathrm{bc}}$ & $63.10^{\mathrm{a}}$ \\
$\mathrm{OM}$ & $64.50^{\mathrm{a}}$ & $56.22^{\mathrm{c}}$ & $59.78^{\mathrm{bc}}$ & $65.76^{\mathrm{a}}$ \\
$\mathrm{CP}$ & $70.60^{\mathrm{b}}$ & $60.53^{\mathrm{c}}$ & $71.38^{\mathrm{ab}}$ & $75.03^{\mathrm{a}}$ \\
$\mathrm{CF}$ & $49.10^{\mathrm{a}}$ & $14.61^{\mathrm{c}}$ & $10.91^{\mathrm{c}}$ & $35.77^{\mathrm{b}}$ \\
EE & $89.33^{\mathrm{b}}$ & $90.98^{\mathrm{ab}}$ & $92.11^{\mathrm{a}}$ & $91.72^{\mathrm{ab}}$ \\
NEF & $66.70^{\mathrm{c}}$ & $77.04^{\mathrm{a}}$ & $76.40^{\mathrm{a}}$ & $74.77^{\mathrm{ab}}$ \\
Nutritive values: & & & & \\
TDN & $61.18^{\mathrm{ab}}$ & $52.19^{\mathrm{c}}$ & $57.91^{\mathrm{b}}$ & $63.29^{\mathrm{a}}$ \\
DCP & $11.93^{\mathrm{ab}}$ & $10.07^{\mathrm{c}}$ & $11.80^{\mathrm{ab}}$ & $12.32^{\mathrm{a}}$ \\
\hline a, b, c, d means in the same raw with different superscripts differ at $(\mathrm{P}<0.05)$. &
\end{tabular}

Effects of feeding the experimental rations containing $40 \%$ ensiled peanut hulls, with FSLCW or/ and PEG on performance of growing lambs are shown in Table (5). The obtained results revealed that lambs which drank FSLCW $\left(\mathrm{T}_{3}\right)$ appeared higher $(\mathrm{P}<0.05)$ total live weight gain $(10.6 \mathrm{Kg})$ and average daily live weight gain $(151 \mathrm{~g})$ than those fed ration without $\operatorname{FSLCW}\left(\mathrm{T}_{2}\right)$ which detected the least total live weight $\left(6.8 \mathrm{Kg}\right.$ )and average daily live weight $(97 \mathrm{~g})$. The differences between $\mathrm{T}_{3}$ and $\mathrm{T}_{1}$ were not significant $(\mathrm{P}<0.05)$. Lambs in $\mathrm{T}_{4}$ which given $3 \mathrm{~g} \mathrm{PEG} /$ head/day showed significantly $(\mathrm{P}<0.05)$ higher total live weight gain $(13.8 \mathrm{Kg})$ and average daily live weight gain( $197 \mathrm{~g})$ than rations $\mathrm{T}_{3}$ and $\mathrm{T}_{1}$. Data concerning feed intake and feed conversion as shown in Table (5) indicated that lambs in treatments $\mathrm{T}_{3}$ and $\mathrm{T}_{4}$ ingested relatively high quantity of FSLCW (6.1 and $6.6 \mathrm{~L} /$ day or 311 and $337 \mathrm{~g}$ based on DM) detected more daily total dry matter intake. This observation was in agreement with those obtained by Anderson et al. (1974). Data concerning feed conversion indicated that lambs fed on $\mathrm{T}_{4}$ and $\mathrm{T}_{1}$ had lower values being, 7.77 and 8.60 than those fed on $\mathrm{T}_{3}$ being $9.33 \mathrm{~g}$ DMI / g gain, while lambs fed on $\mathrm{T}_{2}$ had the worst feed conversion being $12.01 \mathrm{~g}$ DMI /g gain. Feed conversion ratio expressed as g TDN /g gain had the same trend. These results are in harmony with those suggested by Galloway et al. (1992) and Titus et al. (2000).

Data of economical evaluation of feeding growing lambs on experimental rations are summarized in Table(5). It was found that, the relative profit expressed as net 
profit / feeding cost increased to $151.52 \%$ and $190.6 \%$ in $\mathrm{T}_{3}$ containing FSLCW ( free choice) and $\mathrm{T}_{4}$ containing FSLCW( free choice) plus $3 \mathrm{~g}$ PEG / head / day vs. $\mathrm{T}_{1}(59.62 \%)$ containing $40 \%$ clover hay , respectively.

From the previous results it could be concluded that the improving rule of FSLCW and PEG on performance of growing lambs fed rations containing peanut hulls ensiled with lime and urea is summarized as follows: Phosphopeptide complexe as a combination between whey protein and phosphorus may have an interesting effect on the intestinal absorption of minerals (Moulin and Galzy, 1984). Formation of lactosylurea may be maximizes the utilization of urea in the rumen (Sienkiewicz and Riedel, 1990). The bacterial content of cheese whey also may have a role in increasing of feed efficiency the experimental rations( Bolsen et al., 1995). Supplementation of PEG has good ability to combine with the dietary tannins and phenolic compounds instead of binding with the dietary protein, digestive enzymes, minerals, cellulosic bacteria and proteolytic bacteria, and so it can alleviate the reductions in digestion associated with the presence of tannins and phenolic compounds (Scalbert, 1991; Aerts et al., 1999 and Molan et al., 2001).

Table 5. Average live body weight, feed intake, feed conversion and economic efficiency of growing lambs fed the experimental rations

\begin{tabular}{lcccc}
\hline \multirow{2}{*}{ Items } & \multicolumn{4}{c}{ Experimental rations } \\
\cline { 2 - 5 } & $\mathrm{T}_{1}$ & $\mathrm{~T}_{2}$ & $\mathrm{~T}_{3}$ & $\mathrm{~T}_{4}$ \\
\hline No. of animals & 5 & 5 & 5 & 5 \\
Experimental period (days) & 70 & 70 & 70 & 70 \\
Initial live body weight (IBW), (kg) & 28.4 & 28.2 & 29.2 & 29.6 \\
Final live body weight (FBW), (kg) & $39.0^{\mathrm{ab}}$ & $35.0^{\mathrm{b}}$ & $39.8^{\mathrm{a}}$ & $43.4^{\mathrm{a}}$ \\
Total live weight gain, kg & $10.6^{\mathrm{b}}$ & $6.8^{\mathrm{c}}$ & $10.6^{\mathrm{b}}$ & $13.8^{\mathrm{a}}$ \\
Average daily live weight gain, gm & $151^{\mathrm{b}}$ & $97^{\mathrm{c}}$ & $151^{\mathrm{b}}$ & $197^{\mathrm{a}}$ \\
Feed intake: & & & & \\
Feed mixture g/d (DM) & 1299 & 1165 & 1098 & 1193 \\
Cheese whey (liquid) L/d & 0.0 & 0.0 & 6.1 & 6.6 \\
Cheese whey (DM) g/d (w/v) & 0.0 & 0.0 & 311 & 337 \\
Total dry matter intake (g/d) & 1299 & 1165 & 1409 & 1530 \\
TDN (g/d) & 795 & 608 & 816 & 968 \\
Feed conversion (g feed /g gain): & & & & \\
DMI & 8.60 & 12.01 & 9.33 & 7.77 \\
TDN & 5.27 & 6.27 & 5.40 & 4.91 \\
Economical evaluation: & & & & \\
Feeding cost (LE /head/day) & 2.08 & 1.40 & 1.32 & 1.49 \\
Gain price (LE /head/day) & 3.32 & 2.13 & 3.32 & 4.33 \\
Profit (LE /head/day) & 1.24 & 0.73 & 2.00 & 2.84 \\
Relative profit ( profit / feeding cost \% ) & 59.62 & 52.14 & 151.52 & 190.60 \\
Economic improvement (\%) & 100 & 87 & 254 & 320 \\
\hline a & & & & \\
\hline
\end{tabular}

$\mathrm{a}, \mathrm{b}, \mathrm{c}, \mathrm{d}$ means in the same raw with different superscripts differ at $(\mathrm{P}<0.05)$.

RationsT3 and T4 contain $22 \%$ cheese whey (DM basis).T4 contain 3 PEG g/head/day.

The relative profit was calculated as a percentage ratio between profit and feeding cost /head /day. Based on market prices at the beginning of experiment, the price (LE/ton) were 1600 for $\mathrm{T}_{1}, 1200$ for $\mathrm{T}_{2}$ and $\mathrm{T}_{3}$,

1250 for $\mathrm{T}_{4}$ and FSLCW has no market price. The price of one $\mathrm{Kg}$ live body weight on selling was LE 22 . 
Data of rumen liquor parameters presented in Table (6) shows a significant decrease $\quad(\mathrm{P}<0.05)$ in $\mathrm{NH}_{3}-\mathrm{N}$ concentration of rations $\mathrm{T}_{3}$ and $\mathrm{T}_{4}$ compared with $\mathrm{T}_{2}$ after 2 hrs. of feeding being 31.27, 26.87 and $41.33 \mathrm{mg} / 100 \mathrm{ml}$ rumen liquor respectively. After 4 hrs. $\mathrm{T}_{3}$ showed significant $(\mathrm{P}<0.05)$ higher concentration of $\mathrm{NH}_{3}-\mathrm{N}$ compared with $\mathrm{T}_{2}$ and $\mathrm{T}_{4}$, being $26.23,16.80$ and $19.13 \mathrm{mg} / 100 \mathrm{ml}$ respectively. These results might be due to the effects of FSLCW and PEG on the activity of rumen bacteria which consume much amount of ammonia for its growth or/ and to the formation of lactosylurea (direct reaction between lactose and urea) which acts as a reservoir of ammonia for long time. These results agreed with those obtained by Wright (1967), Moulin and Galzy (1984), Stock et al. (1986), Sienkiewicz and Riedel (1990) and Gaggiotti et al. (2002). The values of TVFA's were significantly higher $(\mathrm{P}<0.05)$ in FSLCW and FSLCW + PEG groups $\left(\mathrm{T}_{3}\right.$ and $\left.\mathrm{T}_{4}\right)$ compared with $\mathrm{T}_{2}$, being 10.33 and 10.17 vs. $8.83 \mathrm{meq} / 100 \mathrm{~mL}$ rumen liquor after 2 hrs. while after $4 \mathrm{hrs}$, concentration of TVFA's was the highest significantly $(\mathrm{P}<0.05)$ in FSLCW + PEG $\left(\mathrm{T}_{4}\right)$, being $13.0 \mathrm{meq} / 100 \mathrm{~mL}$ rumen liquor. Higher TVFA's concentrations as a result to FSLCW and PEG supplementation may be attributed to their ability to improve the digestibility of most nutrients in the rumen (Galloway et al.,1992 and Salawu et al., 1997). Supplementation of whey protein as a rapid degradable protein may be a supplier of a specific amino acids or peptides (limiting bacterial growth) which are used to form branched-chain VFA that are required by certain bacteria for optimum growth and so optimum microbial protein synthesis (Stock et al., 1986).

Table 6. Mean values of rumen and blood parameters of growing lambs fed the experimental rations

\begin{tabular}{|c|c|c|c|c|c|}
\hline \multirow[t]{2}{*}{ Items } & \multirow{2}{*}{$\begin{array}{l}\text { Time } \\
\text { (hours) }\end{array}$} & \multicolumn{4}{|c|}{ Experimental rations } \\
\hline & & T1 & T2 & T3 & T4 \\
\hline \multicolumn{6}{|c|}{ Rumen parameters: } \\
\hline \multirow[t]{4}{*}{ pH } & 0 & 6.97 & 7.08 & 6.99 & 7.30 \\
\hline & 2 & 6.18 & 6.23 & 6.21 & 5.94 \\
\hline & 4 & $6.87^{\mathrm{ab}}$ & $7.05^{\mathrm{a}}$ & $6.26^{\mathrm{b}}$ & $5.56^{\mathrm{c}}$ \\
\hline & mean & 6.67 & 6.79 & 6.48 & 6.27 \\
\hline \multirow[t]{4}{*}{ TVFA's (meq/100mL) } & 0 & 6.50 & 5.83 & 6.17 & 5.50 \\
\hline & 2 & $11.17^{\mathrm{a}}$ & $8.83^{\mathrm{b}}$ & $10.33^{\mathrm{a}}$ & $10.17^{\mathrm{a}}$ \\
\hline & 4 & $9.67^{\mathrm{b}}$ & $6.83^{\mathrm{c}}$ & $7.17^{\mathrm{c}}$ & $13.00^{\mathrm{a}}$ \\
\hline & mean & 9.11 & 7.16 & 7.89 & 9.56 \\
\hline \multirow[t]{5}{*}{ NH3- N (mg/100mL) } & 0 & 15.40 & 16.33 & 18.67 & 17.73 \\
\hline & 2 & $16.33^{\mathrm{d}}$ & $41.33^{\mathrm{a}}$ & $31.27^{\mathrm{b}}$ & $26.87^{\mathrm{c}}$ \\
\hline & 4 & $16.33^{\mathrm{b}}$ & $16.80^{\mathrm{b}}$ & $26.23^{\mathrm{a}}$ & $19.13^{b}$ \\
\hline & mean & 16.02 & 24.82 & 25.39 & 21.24 \\
\hline & \multicolumn{5}{|c|}{ Blood parameters: } \\
\hline Total protein ( g / dL ) & 0 & $8.27^{\mathrm{d}}$ & $14.63^{\mathrm{a}}$ & $12.30^{\mathrm{b}}$ & $10.00^{\mathrm{c}}$ \\
\hline Albumin ( g / dL ) & 0 & $3.57^{\mathrm{b}}$ & $4.68^{\mathrm{a}}$ & $3.53^{b}$ & $4.80^{\mathrm{a}}$ \\
\hline Globulin ( g / dL ) & 0 & $4.7^{\mathrm{b}}$ & $9.97^{\mathrm{a}}$ & $8.77^{\mathrm{a}}$ & $5.20^{\mathrm{b}}$ \\
\hline GOT ( U / L ) & 0 & $40.07^{\mathrm{c}}$ & $79.4^{\mathrm{a}}$ & $80.17^{\mathrm{a}}$ & $51.00^{\mathrm{b}}$ \\
\hline GPT ( U / L ) & 0 & $20.33^{\mathrm{c}}$ & $30.33^{\mathrm{a}}$ & $30.67^{\mathrm{a}}$ & $25.63^{b}$ \\
\hline
\end{tabular}

$\mathrm{a}, \mathrm{b}, \mathrm{c}, \mathrm{d}$ means in the same raw with different superscripts differ at $(\mathrm{P}<0.05)$ 
Data of blood serum parameters presented in Table $(6)$ shows higher $(\mathrm{P}<0.05)$ levels in total protein, albumin, globulin, GOT and GPT by feeding on ration $\mathrm{T}_{2}$ (containing ensiled peanut hulls) than $\mathrm{T}_{1}$ (containing clover hay), being 14.63, 4.68 , $9.97,79.4$ and 30.33 vs. $8.27,3.57,4.7,40.07$ and 20.33, respectively. Feeding lambs on rations $\mathrm{T}_{3}$ and $\mathrm{T}_{4}$ supplemented by FSLCW or / and FSLCW + PEG decreased significantly blood parameters to be around normal levels. From the previous results it could be concluded that the high concentrations over the normal limits $T_{2}$ may refer to that the animals were under stress by feeding rations containing in anti-nutritional factors as tannins derivatives or high level of urea which may induce over limit globulin (immunoglobulin), GOT and GPT. These results are in harmony with the results of Dodak and Zboril (1976) who stated that, GOT and GPT were increased by coumarin and Arunachalam and Sivakumar (2003) also found that total protein, albumin and globulin increased significantly under stress. On the other hand, the decreasing in values of blood parameters by adding FSLCW and PEG $\left(\mathrm{T}_{4}\right)$ might indicate a low stress in the liver to detoxicate any harmful effect due to feeding of tanniniferous feeds ensiled with urea (Russel and Lolly, 1989) .

Generally, the performance and economic efficiency of growing lambs fed total mixed rations containing $40 \%$ treated peanut hulls could be improved by used fresh sweet liquid cheese whey in rations and adding polyethylene glycol with drinking water compared with the ration containing $40 \%$ clover hay.

\section{REFERENCES}

Aerts, R.J., W.C. McNabb; A Molan; A Brand; T.N. Batry and J.S. Peters, 1999. Condenced tannis from Louts Corniculatus and Luts Pedunculatus exert different effects on the in vitro rumen degradation of ribulose 1-5 biophosphate carboxylase/oxygenase protein. J. Sci. Food Agric., 79: 79-85.

Aguilera, JF., 1987. Improvement of olive cake and grape by products for animal nutrition. Degradation of lignocellulosics in ruminants and in industrial processes. Nutrition- Abstracts- and Reviews. Series-B, 1988, 058:03320.

Ali, C.S., V.C. Mason and J. Waagepetersen, 1977. The voluntary intake of pelted diets containing sodium hydroxide-treated wheat straw by sheep. 1.The effect of the alkali concentration in the straw. Anim. Feed Sci. and Techno., $14: 139-149$.

Anderson, M.J., R.C. Lbmb; C.H. Mickelson and R.L. Wis-Combe, 1974. Feeding liquid whey to dairy cattle. J.Dairy Sci., $57: 1206$.

A.O.A.C., 1990. Official Methods of Analysis.(15 ${ }^{\text {th }}$ Ed.). Association of Official Analytical Chemists , Arlington, VA.,USA .

Arunachalm,s. and T. sivakumar, 2003 . Blood profile consituents associated with production diseases in Jersy cross breed cows . Indian J. Anim. Sci. , $73: 44-47$.

Aymard, C., J.L. Cuq and J.C. Chefield, 1979.A textbook of Toxic constituents of plant foodstuffs. $2^{\text {nd }} \mathrm{Ed}$, Chapter 12 . Liener, I.E.(ed.),New York ,N.Y.,USA (ISBN 0-12-449960-0).

Barry, T.N. and B.J. Blaney, 1987. Secondary compounds of forages. Anim. Feed Sci. and Techno., 91 :41-57.

Bolsen,K.K., M.A. Young, G.L. Huck, M.K. Siefeis, J.E. Turner, S.A. Anderson, R.V. Pope and J.S. Pendergraft, 1995. Effect of bacterial inoculation on 
preservation efficiency and nutritive value of alfalfa silage for growing cattle. J. dairy Sci., 80( Suppl.:1).

C.L.F.F., 2001. Feed Composition Tables for Animal and Poultry Feedstuffs used in Egypt. Edited by Central Lab for Food \& Feed., Agricultural Research Center, Ministry of Agriculture.

Conway, E.F., 1962. Microdiffusion Analysis And Volumetric Error. Rev. Edt. Lockwood, London, UK.

De Groot, A.P. and P. Stump, 1969. Toxic constituents of plant foodstuffs J. Nutr.98, 45-56.

Dodak , V. and F. Zboril , 1967 . Toxic action of plant phenolic groups . Chem. Coumer. , 32: 411 .

Doumas, B., 1971. Colorimetric determination of albumin. Clin. Chem. Cat., 31: 87.

Duncan, D.B., 1955. Multiple F-test Biometrics, 11:1-42.

El-Talty,Y.I., 1973. Some factors affecting the feeding value of roughages with reference to lignin. Ph. D. Thesis, Fac. of Agric Cairo Univ.

El-talty, Y.I., 1970. Some nutritional studies on the lignin fraction. M. Sc. Thesis, Fac. of Agric. Cairo Univ.

Eskin,N.A.M., H.M. Henderson and R.J. Townsend, 1971. A textbook of plant foodstuffs. $2^{\text {nd }} \mathrm{Ed}$, Chapter 12. Liener, I.E.(ed.), New York ,N.Y.,USA (ISBN 012-449960-0).

Farghaly, M.S., I.M. Awadalla and M.A. Ali, 2003. Effect of urea and lime treatments on feeding value of wheat straw used in growing lambs ration. J. Agric. Mansoura Univ.,28 : 6645 - 6654 .

Franklin E. Barton, II, Henry E. Amos, William J. Albrecht and Donald Burdick, 1974. Treating peanut hulls to improve digestibility for ruminants. J. Anim. Sci., 38:860-846.

Gaggiotti, M.C., M.R. Gallarod, A.A. Abdela, C. Arakaki, L. Burdisso and A.R. Castillo, 2002. Effect of feeding dairy cows with whey permeate on ruminal environment under alfalfa grazing conditions. J. Anim. Sci., 79( Suppl.: 1).

Galloway, D.L. Sr., A.L. Goetsch, W. Sun, L.A. Forester, Jr., G.E. Murphy, E.W. Grant, and Z.B. Johnson, 1992. Digestion, feed intake, and live weight gain by cattle consuming Bermuda grass hay supplemented which whey. J. Anim. Sci., 70:2533-2541.

Gonzalez Siso, M.I., 1996. The biotechnological utilization of cheese whey. Bioresource Technology ,57:1-11.

GOW-CHIN YEN and Pin-Der Duh, 1995. Antioxidant activity of methanolic extracts of peanut hulls from various cultivars. Journal of the American Oil Chemist's Society ,72: 1065-1067.

Granzin, B.C. and G.M. Dryden, 2003. Effects of alkalis, oxidants and urea on the nutritive value of rhodes grass (Chloris gayana cv. Acllide). Anim. Feed Sci. and Techno., 103: 113.

Hartley, R.D., 1981. Chemical constitution, properties and processing of lignocellulosic wastes in relation to nutritional quality of animal. Agric. Anim. Feed Sci. and Techno., $14: 139-149$.

Henery, E.J., 1964. Colorimetric determination of total proteins and calcium. Clin.Chem.Principles and Techniques. Harper and Row, YN, USA. 
Kaneko, T., K. Ushida and Y. Kojima, 1989. Effect of starch on cellulolysis by rumen microbial populations with or without protozoa. J. Anim. Sci., 70:25332541.

Klopfenstein, T.J., V.E. Krause, H.J. Jones and W. Woods, 1979. Chemical treatment of low quality roughages. J. Anim. Sci., 35:418.

Lee,C.M.; T.C. Lee and C.O. Chichester, 1975. Toxic factors induced by processing . Food Sci. and Techno., 1: 587-603.

Molan,A.L.; G.T. Attwood; B.R. Min. and W.C. McNabb (2001). The effect of condensed tannins from Lotus pedunculatus and Lotus corniculatus on the growth proteolytic rumen bacteria in vitro and their possible mode of action. Can.J.Microbial., 47:626-633.

Moulin, G. and P. Galzy (1984). Whey, a potential substracte for biotechnology. Bioresource Technology ,57:1-11.

Nishie, K.; A.C. Waias and A.C. Keyl (1969). Toxic constituents of plant foodstuffs Toxical. Appl. Pharmacol., 14: 301-307.

NRC, (1985). National Research Council, $6^{\text {th }}$ ed. Nutrient Requirements of Sheep. National Academy Press, Washington, DC., USA.

Price,M.L.; L.G. Butler ; J.C. Rogler and W.R.Featherston (1979).Overcoming the nutritionally harmful effects of tannins in sorghum grains by treatment with inexpensive chemicals . J.Agric. Food Chem., 27: 441.

Provansal, M., J.L. Cuq and C. Chefiel, 1975. Toxic constituents of plant foodstuffs. Agric. Food Chem., 23:938-943.

Reichert, R.D.; S.E. Fleming and D.J. Schwab, 1980. Tannin deactivation and nutritional improvement of sorghum by anaerobic storage of H2O- , HCL- or $\mathrm{NaOH}$ - treated. J. Agric. Food Chem.,28: 824.

Reitman, S. and S. Frankel, 1957. Colorimetric determination of AST and ALT activity. Amer. J. Clin. Path., 28:56.

Russel, R.W.and J.R. Lolley, 1989. Deactivation of tannin in high tannin milos treatment with urea. J. dairy sci.,72: 2427-2730.

Salawu, M.B., T. Acamovic, C.S. Strrewart and F.D.DeB. Hovell, 1997. Quebracho tannins with or without Browse plus (a commercial of polyethylene glycol) in sheep diets: effect on digestibility of ruminants in vivo and degradation of grass hay in sacco and in vitro. Anim. Feed Sci. and techno., 69: 67-78.

SAS, 1990. User's Guide: Statistic SAS Inst. Gray,NC.

Scalbert, A., 1991. Antimicrobial properties of tannins. Phytochemistry, 30: 38753883.

Sienkiewicz, T. and C.L. Riedel, 1990. Whey and whey utilization. Bioresource Techno., $57: 1-11$.

Silanikove,N., A. Perevolotsky and F.D. Provenza, 2001. Use of tannin-binding chemicals to assay for tannins and their negative postingestive effects in ruminants . Anim. Feed Sci. and Techno., $91: 69-81$.

Sirohi, S.K. and S.N. Rai, 1995. Associative effect of lime plus urea treatment of paddy straw on chemical composition and in-vitro digestibility. Indian J. Anim. Sci ., 65:775.

Slinkard, K. and Singleton V., 1977. Total phenol analysis: Automation and comparison with manual methods Am. J. Eno.Vitic., 28, 49-55. 
Stock R., T. Kiopfenstein, D. Brink, R. Britton and D. Harmon, 1986. Whey as a source of rumen-degradable protein.1. Effects on microbial protein production. J. Anim. Sci., 63: 1561- 1573.

Theander, O. and P. Aaman, 1984. Antimicrobial and chemical characteristics. Anim. Feed Sci. and Techno.,73: 243-2610.

Theriez, M. and G. Boule, 1970. Upgreading feeding value of olive cake . Anim. Feed Sci. and Techno., $14: 139-149$.

Titus,C.H., F.D. Provenza, E.A. Burritt, A. Perrvolotsky, N. Silanikove, 2000. Performance for foods varying in macronutrients and tannins by lambs supplemented with polyethylene glycol. J. Anim. Sci., 78: 1443-1449.

Warner, A.C.I., 1964. Production of volatile fatty acids in the rumen: Methods of measurements. Nutr.Abst. and Rev.,34:339.

Wright, D.E., 1967. Metabolism of peptides by rumen microorganisms., Appl. Microbial.15:547. 


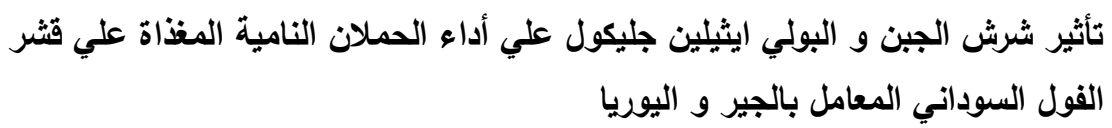

يحيي ابراهيم التلتي' , محمد سيد فرغلي' , رأفت شحاتة ميخائيل'

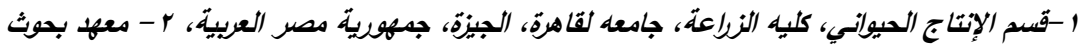

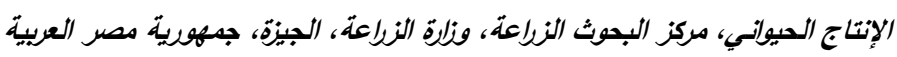

انثتمل هذا البحث علي جزئيين : الأول يهدف إلي دراسة تأثير كمر قثر الفول السوداني لا هوائيا بخليط من

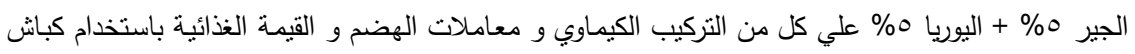

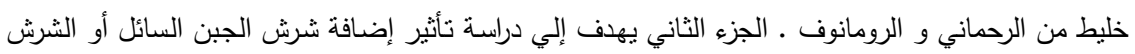

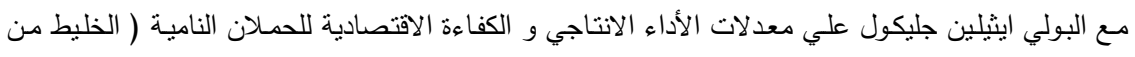

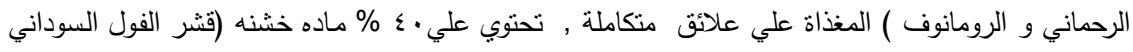

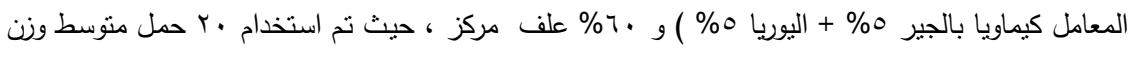

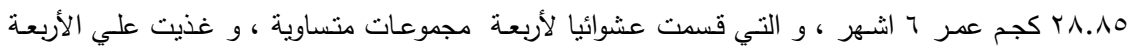

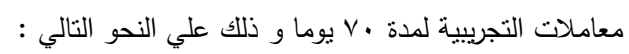

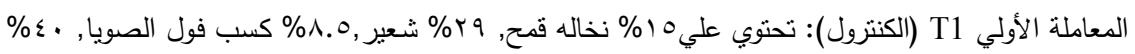

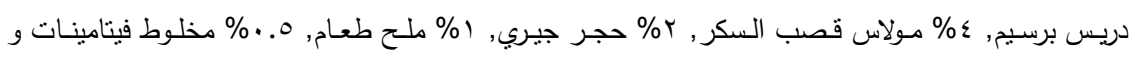

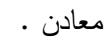
المعاملـة الثانيـة T2 : هي تقريباً نفس المعاملة T1 مـع إستبدال كل دريس البرسيم بقشر الفول السوداني

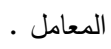

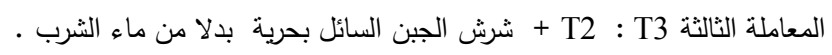

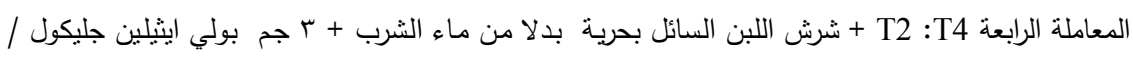

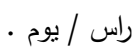
تم توفير الاحتياجات الغذائية من الطاقة و البروتين لنمو الحيوانات لتغطي متوسط الزيادة اليومية طبقا لمقررات

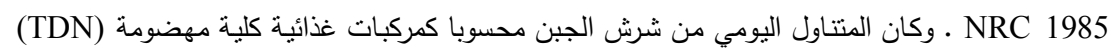

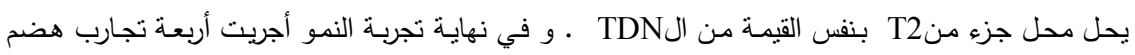
لكأربعة معاملات التجريبية وقدرت فيها بعض قياسات الكرش والدم. وكانت النتائج كالنالي:- التخات أولا : التجربة الأولي (تأثير معاملة قتشر الفول السوداني بالجير واليوريا) .

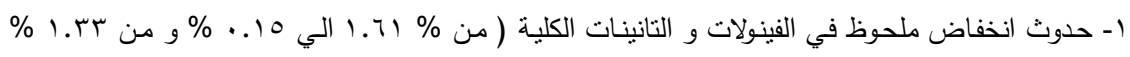

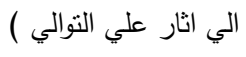


r- انخفاض معنوي لمعاملات هضم البروتين الخام و الالياف الخام و المستخلص الخالي من الازوت

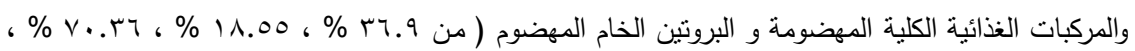

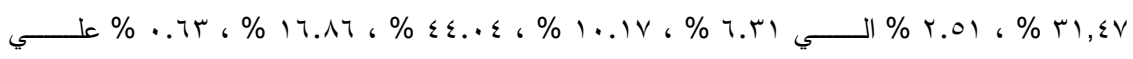

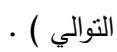

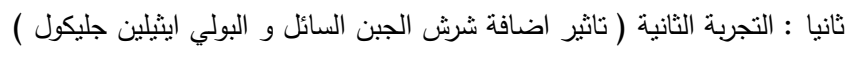

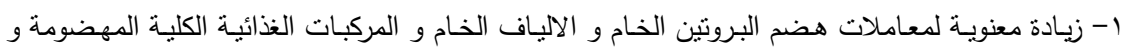

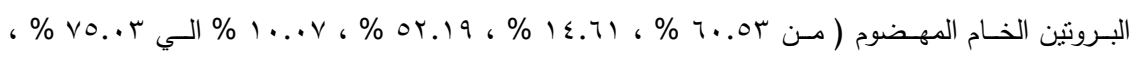

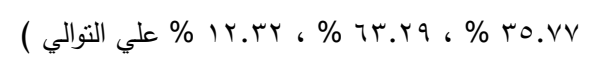

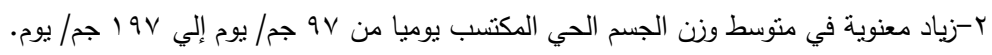

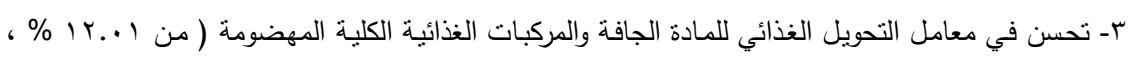

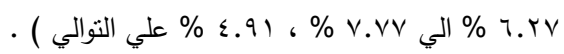

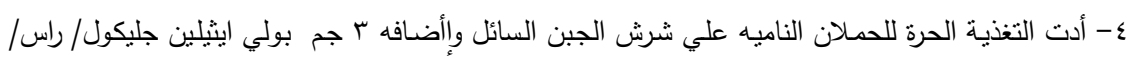

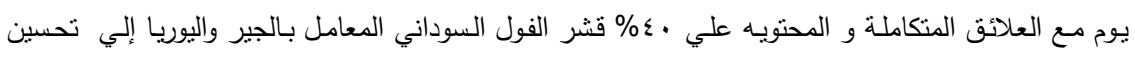

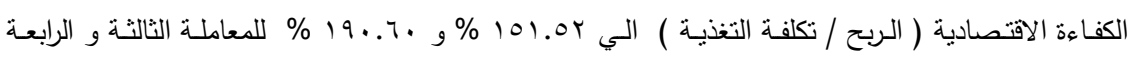

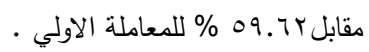

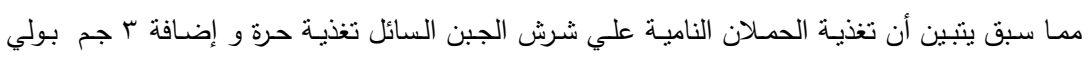

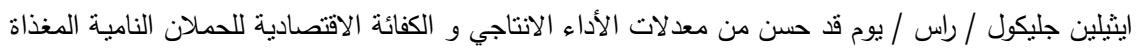

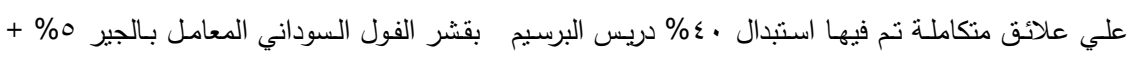
اليوريا 0. . 